\title{
НАУКОВІ ЗАСАДИ ІНТЕЛЕКТУАЛЬНОГО РОЗВИТКУ ОСОБИСТОСТІ УЧНЯ СЕРЕДНЬОЇ ШКОЛИ
}

У статті здійснено аналіз наукових засад інтелектуального розвитку особистості, розглянуто основні теорії розвитку особистості, сучасне розуміння понять інтелекту та структури інтелекту. На основі здійсненого аналізу основних підходів до розуміння інтелекту та розвитку особистості інтелектуальний розвиток особистості визначено як неперервний прочес становлення і формування якісних змін у структурі інтелекту особистості, в основі якого лежать психічні прочеси, мислення та уява, мова і мовлення. Інтелектуальний розвиток знаходиться у прямо пропориійній залежності від навчання, у основі яких лежать зовнішні і внутрішні чинники, найважливішими з яких є наявність стійкої мотивації, розвивального освітнього середовища.

Ключові слова: особистість, розвиток, інтелект, інтелектуальний розвиток, теорії інтелекту, біоекологічна теорія інтелекту.

Орієнтованість українського суспільства на євроінтеграцію обумовлює реформування системи освіти, що спонукало розбудову Нової української школи. Основна мета НУШ - допомогти розкрити та розвинути здібності і можливості кожної особистості. Очікуваним результатом реалізації концепції НУШ є розвиток особистості школяра, зокрема інтелектуальний, що забезпечить здатність навчатися впродовж життя та швидко адаптуватися у суспільних змінах.

Нормативно-правова база сучасної освіти (Концепція Нової української школи, що пройшла обговорення 27.10.2016, Закони України "Про освіту", прийнятий 5 вересня 2017 року № 2145-VIII, "Про загальну середню освіту", прийнятий 13 травня 1999 року №651-XIV, Національна доктрина розвитку освіти в Україні у XXI столітті (2001), та ін.) визначає, що оволодіння знаннями, поглядами та світобаченням у системі сучасної освіти усіх ланок зорієнтовано на забезпечення розвитку особистості.

Інтелектуальний розвиток особистості під час навчання $є$ найбільш важливим завданням теорії та методики сучасної освіти. Відтак існує об'єктивна потреба дослідження проблем розвитку особистості, інтелекту, інтелектуального розвитку. Найважливішим аспектом розв'язання піднятої проблеми $\epsilon$ окреслення наукових засад інтелектуального розвитку особистості.

Аналіз основних досліджень і публікацій із зазначеної проблеми. Дослідження інтелектуального розвитку особистості грунтується на теоріях розвитку особистості (філософсько-психологічна концепція С. Л. Рубінштейна, психологічна теорія формування особистості через розвиток іiі стосунків В. М. Мясищева, культурно-історична теорія розвитку особистості Л. С. Виготського, теорія Г. С. Костюка, що розглядає особистість "як систему систем", динамічна функціональна психологічна теорія особистості К. К. Платонова, теорія особистості Б. Г. Ананьєва, психологічна теорія особистості як джерела суспільно-трудової активності людини А. Г. Ковальова, теорія виховання всебічно розвиненої особистості В. О. Сухомлинського, соціально-психологічна теорія особистості О. В. Петровського, теорія розвитку у навчальній діяльності О. К. Дусавицького, концепція особистості Г. А. Балла, стратегічна теорія виховання творчої особистості В.О. Моляко, теорія особистісно орієнтованого виховання I. Д. Беха, генетико-психологічна теорія розвитку особистості С. Д. Максименко, дослідження особистості як ноологічної категорії Г. П. Васяновича, В.Д. Онищенко, концепція особистості як трансцендентальної сутності О. В. Вознюка).

Важливими для розуміння розвитку особистості є теорія здібностей (Б. М. Теплова, Б. Г. Ананьєва, В. М. Мясищева, О. Г. Ковальова, К. К. Платонова), та трактування розвитку у зв'язку з розвитком здібностей (С. Л. Рубінштейна, Г. С. Костюка).

Для встановлення взаємозв'язку між інтелектуальним розвитком та навчанням у школі використовуються теорії розвивального навчання (Л. С. Виготського, В. В. Давидова, О. К. Дусавицького, Д. Б. Ельконіна, С. Д. Максименко) та теорії модульно-розвивального навчання (А. М. Алексюка, В. О. Огнев’юк, А. В. Фурмана, С. П. Семенець).

Трактування інтелектуального розвитку неможливе без окреслення змісту таких понять, як інтелект та структура інтелекту. Серед основних теорій інтелекту найбільш вагомими є теорія множинного інтелекту (Говарда Гарднера (1983), Даніеля Гоулмана (1995), Джона Мейера, Пітера Саловея (2000); факторно-аналітичні теорії інтелекту К. Спірмена (1927), Д. Гілфорда (1970), тріархальна теорія інтелекту Стернберга $(1985,1988)$, теорія інтелекту і когнітивного розвитку Андерсона, біоекологічна 
теорія інтелекту Стефана Цесі (J. Сесі, 1990), теорія інтелектуального діапазону В. М. Дружиніна, психологічна модель інтелекту - як ментального досвіду особистості М. О. Холодної).

Однак, не зважаючи на значну кількість досліджень особистості, онтології розвитку, формування інтелекту, не існує єдиного чіткого визначення поняття інтелектуального розвитку особистості.

Також варто відмітити, що предметом наукових пошуків були проблеми сутності та механізмів розвитку особистості, у той же час недостатньо розкрито проблеми засобів, методів та умов інтелектуального розвитку.

Мета дослідження - здійснити науковий аналіз проблеми інтелектуального розвитку особистості, визначити наукові засади інтелектуального розвитку особистості учня у процесі навчання в середній школі.

Виклад основного матеріалу. Проблема становлення і розвитку особистості, розвитку інтелекту складна і багатогранна, що є основною причиною відсутності єдиного загальноприйнятого трактування дефініцій "інтелект" та "інтелектуальний розвиток особистості". М. Л. Смульсон складність і неоднозначність проблеми розвитку інтелекту пов'язує з орієнтацією наукових досліджень на зовнішні прояви психічних явищ, фіксацію їх властивостей, і відсутність пошуків у напрямку вивчення механізмів розвитку, що сформувало думку про стабільність рівня інтелекту впродовж життя людини. Однак М. Л. Смульсон, грунтуючись на працях М. О. Холодної, доводить динамічність інтелекту і вважає, що дослідження процесів розвитку інтелекту дасть можливість розбудовувати відповідні розвивальні середовища.

Розвиток розглядається як необоротна, спрямована, закономірна зміна матеріальних чи ідеальних об'єктів [1].

Г. С. Костюк [2] розробляв принципи розвитку особистості, виходячи з онтогенетичного становлення особистості і пї психічних властивостей. Науковець вважав, що соціальні фактори впливають на психічний розвиток особистості через власну діяльність, завдяки цьому особистість засвоює соціальний досвід, що забезпечує перехід зовнішніх, інтеріндивідуальних ставлень у внутрішні, інтераіндивідуальні властивості особистості. Цей процес залежить від суб'єктивних умов: від відношення особистості до діяльності, їі внутрішньої позиції, значущості даної діяльності для особистості.

Відтак, розвиток особистості відбувається все життя у процесі безперервного навчання, базується на власному і на суспільному досвіді. Провідну роль у розвитку має діяльність, спрямована на суспільно значущих цінностей. Г. С. Костюк вказував, що розвиток особистості керується ззовні, спрямовується суспільством, однак реалізується як процес, який саморозвивається під впливом внутрішніх потреб, джерелом розвитку стають внутрішні протиріччя, що виникають у процесі життя.

Б. Г. Ананьєв розуміє особистість як суспільний індивід, об'єкт і суб'єкт історичного процесу. Підтримуємо його думку стосовно того, що розвиток особистості визначається сукупністю умов соціального існування у дану історичну епоху, особистість конкретно-історична, вона є продуктом своєї епохи і життя країни, тому варто враховувати не тільки процес ії виховання, становлення, а й окремі соціальні умови. Разом з цим особистість не пасивний об'єкт впливу із зовні, вона є активним суб'єктом створення власного середовища. На основі цього варто зазначити, що для розвитку особистості важливе значення має створення відповідного розвиваючого освітнього середовища, враховуючи, що кожен індивід впливатиме на освітнє середовище. Тому оточення особистості має надзвичайно важливе значення у розвитку, наявність індивідів 3 подібною спрямованістю, вмотивованих до розвитку $\epsilon$ стимулом для розвитку інших.

Сучасні психологічні трактовки розвитку [3] зосереджені на розумінні розвитку на основі принципів безперервності (континуальності), антиципації та суб'єктивності. Відтак, всі етапи розвитку взаємопов’язані, наступні стадії розвитку детерміновані попередніми і потребують підготовки, однак суб'єктність розвитку обумовлює невизначеність і унікальність шляхів розвитку, індивідуальністю розвитку окремої особистості та авторства власного розвитку. Детермінованість послідуючих етапів розвитку у педагогіці трактується на основі теорії поетапного формування розумових дій і прийомів розумової діяльності (П. Я. Гальперін, Н. Ф. Тализіна).

Відтак, розвиток особистості - це безперервний необоротний, закономірний процес, що складається 3 певних стадій і залежить не лише від зовнішніх впливів, а й від власної активності особистості.

В. Н. Мясищев наголошував, що "вивчаючи особистість, іiі можна вивчати лише у діяльності". Основною рушійною силою є діяльність. Як наслідок, інтелектуальний розвиток особистості учня не залежить від процесу научіння. На основі досліджень С. П. Семенця [4], встановлено, що реальні можливості для становлення і інтелектуального розвитку особистості притаманні суб'єкту, що прагне до розвитку через власну діяльність. Науковець вказує, що "розвиток учня - це процес його самотворення як особистості у діяльності. Такою діяльністю є навчальна, що виступає формою засвоєння теоретичних знань у процесі розв’язання навчальних задач" [1].

Функціонування інтелекту можна пояснити на основі біоекологічної теорії інтелекту Стефана Цесі (Cесі, 1990) [2], згідно з якою інтелект визначається не лише на основі IQ чи інших біологічних 
показників, а формується внаслідок взаємодії між когнітивними потенціалами і добре організованою базою знань. Стефан Цесі використовує поняття "екологічна ніша", яку займає кожна особистість, що включає можливості, закладені в індивідуальному оточенні чи контексті. Контекст - це особливості особистості, внутрішня мотивація, рівень освіченості і сформованості компетентності у галузях, де самореалізується індивід. Помічено, що індивіди, які не наділені значними здібностями до абстрактного мислення, а володіють достатнім запасом знань та умінь у потрібній галузі, є більш успішними при виконанні поставлених завдань і розв'язанні задач.

М. Л. Смульсон $[5,6]$ у своїх дослідженнях робить висновок, що крім конкретного (практичного) та академічного інтелекту, виділяють також соціальний інтелект - як вид інтелекту, який забезпечує ефективність соціальної активності особистості, є специфічною формою організації ментального досвіду в сфері соціальної взаємодії, виявляється в спілкуванні, спільній діяльності, груповій взаємодії, менеджменті.

Також виокремлюють емоційний інтелект - групу розумових здатностей, які допомагають сприйняти і зрозуміти власні почуття і почуття інших людей, а також регулювати власні почуття (Г. Алдер, О. П. Саннікова). Однак численні дослідження вітчизняних та зарубіжних фахівців показали, що інтелект - це багатоаспектний конструкт.

В. М. Дружинін створив теорію інтелектуального діапазону, в основі якої уявлення про наявність ієрархічних взаємозалежних зв'язків між різними факторами інтелекту. В. М. Дружинін розкриває поняття феномена "лівого зсуву" кривої розподілу показників числового інтелекту. Відтак, вербальний і просторовий інтелект пов'язані між собою, але не простою кореляційною залежністю. Верхньою межею значення просторового інтелекту $\epsilon$ рівень розвитку вербального інтелекту. Але високорозвинений вербальний інтелект не завжди визначає розвиток просторового інтелекту. Тобто, розвиток вербального інтелекту є лімітуючою, але не єдиною умовою розвитку просторового інтелекту. Аналогічна залежність існує між числовим і просторовим інтелектами. Просторовий інтелект $є$ обмежуючим фактором для розвитку числового інтелекту, відтак розвиток просторового інтелекту є необхідною, але не єдиною умовою розвитку числового інтелекту.

Модель В. М. Дружиніна вибудовує ієрархічну структуру відношень різних видів інтелекту. Фундаментом інтелектуального розвитку особистості є вербальний інтелект, над ним надбудовується просторовий, і лише при високорозвинених вербальному і просторовому інтелектах розвивається числовий. Теорія інтелектуального діапазону $\quad$ В. М. Дружиніна пояснює не лише ієрархію інтелектуального розвитку, а й генетичний розвиток одних здібностей на базі інших в онтогенезі.

Існує модель успішного інтелекту, автором якої є О. Ю. Буров. Ця модель пояснює структуру інтелекту, яка включає академічний (логіко-математичний, лінгвістичний, візуально-просторовий, кінестичний інтелект) персональний (самосвідомість, самоаналіз, самоадаптація), міжіндивідуальний (чутливість, емпатію), соціальний, практичний, емпіричний (здатність впоратися з новою ситуацією, опрацьовувати інформацію), креативний інтелекти.

Отже, структура інтелекту включає такі складові:

когнітивний потенціал - розумові здібності індивіда, різні аспекти мислення; здатність визначати проблему і розробляти алгоритми їі розв'язання;

добре організована база знань: загальна поінформованість, рівень навченості, адаптивна система, що забезпечує ефективність взаємодії із середовищем [7].

Розвиток мислення характеризується наступною сукупністю показників: сформованість розумових дій подумки; високий рівень розвитку процесів аналізу та синтезу; здатністю перенесенням сформованих раціональних прийомів мисленнєвої діяльності на завдання та проблеми, які потрібно вирішувати індивіду; системності і глибиною знань.

Процес розвитку мислення відбувається поступово від сформованості репродуктивних дій до розвитку продуктивних мисленнєвих дій, які можна розмежувати на чотири основні групи: практичні і відтворювальні дії; мислиннєві дії; контролюючі, оцінюючі та творчі дії; здатність до цілепокладання (планування).

Отже, мислиннєва діяльність, зокрема критичне, просторове та дивергентне мислення, виступає у ролі внутрішньої умови, яка впливає на подальший розвиток розумових здібностей людини.

Висновки та перспективи подальшого дослідження проблеми. Одним 3 пріоритетів сучасної освіти $є$ збереження розвивального потенціалу навчання. Розвиток особистості - це безперервний необоротний, закономірний процес, що складається 3 певних стадій і залежить не лише від зовнішніх впливів, а й від власної активності особистості.

Розвиток - процес зміни, руху від більш низького до більш високого, від простого до більш складного. Розвиток особистості у процесі навчання, у першу чергу, розглядається як інтелектуальний. Основним проявом інтелекту є здатність до мислення. Мислення є процесом функціонування інтелекту, а розвиток інтелекту обумовлює якість розумової діяльності. 
Розвиток особистості відбувається через включення у діяльність. Діяльність учня повинна бути наближеною до дослідницької і містити такі дії: усвідомлення та аналіз ситуації, виокремлення проблемних аспектів і планування шляхів розв’язання проблеми, пошук інформації, оцінка інформації та засобів розв'язання проблеми, висування гіпотез та їх обгрунтування, перевірка гіпотез, оцінка та аналіз отриманих результатів, узагальнення та формулювання висновків.

Інтелектуальний розвиток - це неперервний процес становлення і формування якісних змін у структурі інтелекту особистості, в основі якого лежать основні психічні процеси, мислення та уява, мова і мовлення. Розвиток інтелекту відбувається паралельно з процесами навчання, залежить від зовнішніх і внутрішніх чинників, найважливішими 3 яких $\epsilon$ наявність мотивації, розвивального освітнього середовища.

Інтелект багатогранний і має ієрархічну структуру, що включає вербальний, просторовий, числовий, емоційний інтелект. У рамках проведеного дослідження виокремлюємо такі складові інтелектуального розвитку особистості, як когнітивний потенщіал та добре організовану, систематизовану базу знань, що забезпечує ефективність особистості у іiі взаємодії середовищем та високу компетентність у обраній галузі самореалізації.

Інтелектуальний розвиток супроводжується формуванням інтелектуальних умінь, серед яких базовими є логічні операції, уміння мотивувати власну розумову діяльність, концентруватися на проблемі, шукаючи засоби та шляхи їі розв'язання, оцінювати інформацію, виконуючи мислиннєві операції; творчо використовувати знання.

\section{СПИСОК ВИКОРИСТАНИХ ДЖЕРЕЛ ТА ЛІТЕРАТУРИ}

1. Семенець С. П. Концепція моделі навчально-математичної діяльності учнів / С. П. Семенець // Педагогіка вищої і середньої школи. - 2017. - Вип. 1(50). - С. 137-146

2. Введение в психологию / [Аткинсон Р. С., Аткинсон Э. Е., Смит Д. Дж., Бем С. Нолен-Хоэксема]; за ред.В. П. Зинченко. - Санкт-Петербург : Прайм-Еврознак, $2007-672$ с

3. Анцыферова Л. И. Способность личности к преодолению деформации свого развития / Л. И. Анцыферова // Развитие личности и проблемы геронтопсихологии. - М. : Изд-во "Институт психологии РАН", 2006. С. $355-381$.

4. Семенець С. П. Особистісно-розвивальне навчання математики: діяльнісний вимір // Креативна педагогіка : [наук.-метод. журнал] / С. П. Семенець // Академія міжнародного співробітництва 3 креативної педагогіки "Полісся". - Житомир, 2016. - Вип. 11.

5. Смульсон М. Л. Психологія розвитку інтелекту у ранній юності : автореф. дис. доктора псих.наук : спец 19.00.07 - "Педагогічна та вікова психологія" / М. Л. Смульсон. - Київ, 2002. - 40 с.

6. Смульсон М. Л. Інтелект і ментальні моделі світу / М. Л. Смульсон // Наукові записки. - Серія "Психологія і педагогіка". Тематичний випуск "Сучасні дослідження когнітивної психології" - Острог: Вид-во Національного університету "Острог", 2009. - Вип. 12. - С. 38-49.

7. Ващук О. В. Інтелектуальний розвиток особистості школярів у проесі вивчення природничих дисциплін [Електронний ресурс]/ О. В. Ващук. - Режим доступу: https://naurok.com.ua/intelektualniy-rozvitokosobistosti-shkolyariv-u-procesi-vivchennya-prirodnichih-disciplin-2494.html. - Систем. вимоги : Реntium ;32 Мb RAM ; Windows 95, 98, 2000, XP ; MS Word 97-2000. - Назва з контейнера.

\section{REFERENCES (TRASLATED \& TRANSLITERATED)}

1. Semenets S. P. Kontseptsiia modeli navchal'no-matematychnoi diial'nosti uchniv [Concept of Model of Educational and Mathematical Activity of Students] // Pedahohika vyshchoi i serednoi shkoly [Pedagogy of Higher and Secondary Schools]. - 2017. - Vyp. 1 (50). - S. 137-146.

2. Vvedeniie v psykholohiiu [Introduction to Psychology] / [Atkynson R. S., Atkynson E. E., Smyt D. Dzh., Bem S. Nolen-Khoeksema] ; za red.V. P. Zinchenko. - Sankt-Peterburh : Praim-Evroznak, 2007 - 672 s

3. Antsiferova L. I. Sposobnost' lichnosti k preodoleniiu deformatsii svoho razvitiia [The Ability of the Individual to Overcome the Deformation of His / Her Development] / L. I. Antsiferova // Razvitiie lichnosti y problemi herontopsykholohii [Development of the Personality and Problems of Gerontopsychology]. - M. : Izd-vo "Institut psykholohii RAN", 2006. - S. 355-381.

4. Semenets S. P. Osobystisno-rozvyval'ne navchannia matematyky : diial'nisnyi vymir [Personality Developmental Training of Mathematics : Activity Measurement] / S. P. Semenets // Kreatyvna pedahohika [Creative Pedagogy] : [nauk.-metod. zhurnal]. - Akademiia mizhnarodnoho spivrobitnytstva z kreatyvnoi pedahohiky "Polissia". Zhytomyr, 2016. - Vyp. 11.

5. Smulson M. L. Psykholohiia rozvytku intelektu u rannii yunosti [Psychology of the Development of Intelligence in Early Adolescence] : avtoref.dys. doktora psykh.nauk : spets 19.00.07 - "Pedahohichna ta vikova psykholohiia" / M. L. Smulson. - Kyiv, 2002. $-40 \mathrm{~s}$.

6. Smulson M. L. Intelekt i mental'ni modeli svitu [Intelligence and Mental Models of the World] / M. L. Smulson // Naukovi zapysky. Seriia "Psykholohiia i pedahohika". Tematychnyi vypusk "Suchasni doslidzhennia kohnityvnoi psykholohii" [Academic Writings. Psychology and Pedagogics Series. Theme Issue "Current Research of Cognitive Psychology"]. - Ostroh : Vyd-vo Natsional'noho universytetu "Ostroh", 2009. - Vyp.12. - S. 38-49.

7. Vashchuk O. V. Intelektualnyi rozvytok osobystosti shkoliariv u protsesi vyvchennia pryrodnychykh dystsyplin [Intellectual Development of the Personality of Students' in the Process of Studying Natural Sciences] [Elektronnyi 
resurs] / O. V. Vashchuk. - Rezhym dostupu : https://naurok.com.ua/intelektualniy-rozvitok-osobistosti-shkolyarivu-procesi-vivchennya-prirodnichih-disciplin-2494.html - System. vymohy : Pentium ; 32 Mb RAM ; Windows 95, 98, 2000, XP ; MS Word 97-2000. - Nazva z konteinera.

\section{Ващук Е. В. Научные основы интеллектуального развития личности ученика средней иколы.}

В статье проведен анализ научных основ интеллектуального развития личности, рассмотрены основные теории развития личности, современное понимание понятий интеллекта и структуры интеллекта. На основе проведенного анализа основных подходов к пониманию интеллекта и развития личности интеллектуальное развитие личности определено как непрерывный процесс становления и формирования качественных изменений в структуре интеллекта личности, в основе которого лежат психические процессы, мышление и воображение, язык и речь. Интеллектуальное развитие находится в прямо пропорииональной зависимости от обучения, в основе которых лежат внешние и внутренние факторы, важнейшими из которых является наличие устойчивой мотиваџии, развивающая образовательная среда.

Ключевые слова: личность, развитие, интеллект, интеллектуальное развитие, теории интеллекта, биоэкологическая теория интеллекта.

\section{Vashchuk O. V. Scientific Principles of Intellectual Development of Personality of Secondary School Pupils.}

The intellectual development of the individual during the process of education is the most important issue of the theory and methodology of modern education. Therefore, there is an urgent need to study the problems of the development of personality, intelligence and intellectual development. The most vivid aspect of solving this burning issue is the outline of the scientific foundations of intellectual development of the individual.

Despite a large number of studies of personality, its development and the intelligence as phenomenon, there is no single clear definition of the concept of intellectual development of an individual.

It should be noted, that the subject of scientific research was the issue of the essence and mechanisms of personality development. At the same time, the problems of means, methods and conditions of intellectual development were not sufficiently solved.

Aim of the research is to carry out a scientific analysis of the problem of intellectual development of an individual, as well as to determine the scientific principles of intellectual development of the student's personality in the process of studying in a secondary school.

One of the priorities of modern education is to preserve the developmental potential of learning. The development of personality is a continuous, irreversible, natural process consisting of certain stages. It depends not only on external influences, but also on the individual's own activity.

Development is identified as a process of change, the constant motion from lower to higher and from simple to more complex. In the same time, the development of an individual occurs through inclusion in the activity. The activities of the student should be close to the research process and include the following actions: awareness and analysis of the situation; the identification of problem and its aspects, as well as planning of ways to solve the particular issue; finding and evaluating information and means of solving the problem; hypothesis and its justification, together with the hypothesis testing, assessment and the analysis of the results; generalization and formulation of the conclusions.

Intellectual development is a continuous process of formation of qualitative changes in the structure of intelligence of an individual, which is based on the basic psychical processes, thinking and imagination, language and speech.

The development of intelligence occurs in parallel with the educational process and depends on external and internal factors, the most important of which is the presence of motivation, development-friendly environment. In the structure of intelligence, the following components are distinguished: cognitive potential, which is identified as thinking in various aspects of its manifestation; mental capabilities of an individual; the ability to determine the problem and develop algorithms for its solution and a well-organized knowledge base: general awareness, level of training, adaptive system, ensuring the effectiveness of interaction with the environment.

Intellectual development is accompanied by the formation of intellectual skills. Intellectual skills are identified as a system of intellectual actions, which consists of logical operations (techniques) and promotes the assimilation of knowledge and the development of intellectual abilities of an individual. Intellectual skills is a set of skills, that combines the ability of pupils to motivate their cognitive activity; concentrate on perceiving information and assimilating it; carry out thoughtful operations; creatively use acquired knowledge; work independently with the study book and reference literature.

Key words: personality, development, intelligence, intellectual development, theory of intelligence, bio-ecological theory of intelligence. 